УДК 574

\author{
А. А. Ромась, \\ М. А. Гуцол, \\ ${ }^{[0000-0001-5252-8737]}$ С. В. Нагірняк, к.m.н., \\ ${ }^{[0000-0001-8189-8665]}$ T. А. Донцова, א.х.н., доиент \\ Національний технічний університет України \\ «Київський політехнічний інститут імені Ігоря Сікорського» \\ просп. Перемоги, 37, м. Київ, 03056, Україна
}

\title{
ПЕРСПЕКТИВИ ВИКОРИСТАННЯ СЕНСОРНОГО МЕТОДУ ДЛЯ ВИЗНАЧЕННЯ ЯКОСТІ ІРУНТІВ
}

Дослідження складу трунтового повітря є надзвичайно важливою задачею, оскільки вміст компонентів газової фази трунту, зокрема $\mathrm{CO}_{2}$ та $\mathrm{O}_{2}$, безпосереднім чином відображає показники родючості трунту. В роботі проведено огляд щодо компонентного складу трунтового повітря, розглянуто існуючі методи визначення дихання трунту та показано перспективність використання сенсорного методу, який базується на використанні масиву датчиків, з можливістю проведення онлайн моніторингу без використання реагентів. 3 метою визначення чутливості синтезованих зразків відносно $\mathrm{CO}_{2}$ методом паро-газового транспорту синтезовано одновимірні наноструктури стануму (IV) оксиду та проведено їх модифікацію ітрієм для використання в чутливих шарах газових сенсорів. Досліджено вольт-амперні характеристики чистих та модифікованих наноструктур $\mathrm{SnO}_{2}$ на повітрі та в атмосфері карбон (IV) оксиду.

Ключові слова: типи трунтів, дихання трунту, наностуктури стануму(IV) оксид, мультисенсорна система, е-поле, система закритого трунту.

Вступ. Показники родючості грунту безпосереднім чином пов'язані зі складом грунтового повітря, так званим «диханням землі», що відіграє важливу роль у живленні рослин та є індикатором біохімічних і біологічних процесів, які відбуваються в грунті. Склад грунтового повітря постійно змінюється внаслідок обміну між повітрям атмосфери та повітрям грунту. Газова фаза грунту близька до атмосферного повітря, але відрізняється більш високим відсотком карбон (IV) оксиду, меншим вмістом кисню, наявністю сірководню та метану, а у випадку передозування добривами може призвести до появи оксидів нітрогену.

3 усіх газів грунтового повітря найбільш динамічними $є$ кисень та карбон (IV) оксид. Оптимальний вміст кисню в газовій фазі грунту становить приблизно $20 \%$. Відомо, що вміст $\mathrm{CO}_{2}$ в грунтовому повітрі завжди $\epsilon$ вищим, ніж в атмосферному і становить від $0,2-0,5 \%$ до $1 \%$. Від концентрації $\mathrm{CO}_{2}$ залежить ріст рослин, і при досягненні його оптимальної концентрації можна прискорити зростання культури. Кисень грунтового повітря має важливе значення для родючості грунту та необхідний, перш за все, для мікробіологічних процесів. Він активно бере участь у хімічних реакціях мінеральних i органічних речовин та інтенсивно поглинається коренями рослин і мікробами в процесі їх дихання. Відсутність вільного кисню, аналогічно до накопичення вуглекислоти, за умови надлишкового зволоження грунту пригнічує ріст та розвиток рослин. Негативний вплив грунтового повітря проявляється при вмісті кисню, меншому за 8-12 \% від загального об'єму, а при вмісті кисню в грунті, меншому $5 \%$, більша частина рослин гине.

Дихання трунтів. Грунт є динамічним, багатофазним елементом біосфери i знаходиться в постійному взаємозв'язку 3 гірськими породами, природними та атмосферними водами. В грунті присутні як гази $\left(\mathrm{N}_{2}, \mathrm{O}_{2}, \mathrm{H}_{2}\right)$, так і пари рідких $\left(\mathrm{H}_{2} \mathrm{O}, \mathrm{NH}_{4}\right)$ та твердих речовин $(\mathrm{Hg}, \mathrm{J})$. У зв'язку з цим склад газової фази грунту $є$ надзвичайно різноманітним і визначається внутрішніми біофізичними, біохімічними процесами та газообміном 3 навколишнім середовищем.

Процес виділення вуглекислого газу та споживання кисню називається «диханням грунту» [1], яке включає біологічні, біохімічні, грунтово-фізичні та геологічні характеристики грунту. Процес газообміну в грунтах поділяється на циклічну та компонентну складо- 
ві. Циклічний газообмін відображає сезонну активність грунтової біоти і послаблюється в холодний період року. Постійна складова виникає внаслідок надходження газоподібних речовин з надр Землі та процесів дегазації осадових відкладень [2].

Грунтове повітря має важливе значення для росту рослин, оскільки: бере участь у хімічних та біохімічних процесах, що відбуваються у грунті; відіграє роль в окисновідновних умовах у грунті; впливає на розчинність хімічних компонентів грунту. Грунтове повітря забезпечує киснем корені рослин і живі організми, присутні в грунті, та $є$ важливим фактором у вуглецевому живленні рослин, оскільки більшість вуглекислого газу, що витрачається на ріст врожаю сільськогосподарських культур, постачається з грунту.

До складу грунтового повітря входять дві групи компонентів - основні речовини та домішки, вміст яких не перевищує 100 ppm. Основними компонентами газової фази є оксиген, вуглекислий газ, азот, аргон та пари води. При надмірному зволоженні грунту за рахунок перебігу процесів анаеробіозису склад грунтового повітря може поповнюватися редукуючими газами, такими як $\mathrm{H}_{2} \mathrm{~S}, \mathrm{H}_{2}$, $\mathrm{CO}, \mathrm{CH}_{4}$, у кількостях на рівні вмісту основних компонентів. Окремі гази можуть знаходитися в грунті у вільному стані (в порах грунту та пустотах), в адсорбованому стані на поверхні грунтових частинок або в розчиненому стані. Найбільше значення має саме вільне грунтове повітря, вміст якого залежить від порозності та вологості грунту.

За нормальної аерації середній склад газової фази грунтів в основному визначається співвідношенням інтенсивності газообміну 3 атмосферою і процесів поглинання $\mathrm{O}_{2}$ та виділення $\mathrm{CO}_{2}$. Інтенсивність поглинання кисню грунтом становить $\mathrm{n}(10 \div 100) \mathrm{Mг} / \mathrm{M}^{2} \cdot$ год, а виділення вуглекислого газу $\mathrm{n}(10 \div 1000) \mathrm{мг} / \mathrm{M}^{2} \cdot$ год [1]. Ці величини інтенсивності можуть сильно варіюватися залежно від термодинамічних умов, характеру грунту та наявності живих організмів у грунті.

На відміну від атмосферного повітря, склад грунтового повітря характеризується вищою динамічністю, яка, в першу чергу, стосується співвідношення між киснем та вуглекислим газом (таблиця 1). Грунтове повітря відрізняється більшим вмістом вуглекислого газу та водяної пари і меншим вмістом кисню.
Склад грунтового повітря значно змінюється в часі (впродовж доби та залежно від сезону) та по профілю грунту залежно від біологічної активності, гідротермічних умов, адсорбції газів та інтенсивності газообміну між грунтом та атмосферою. В результаті біологічних процесів у грунті постійно відбувається поглинання кисню організмами та виділення вуглекислого газу, внаслідок чого грунт збіднюється киснем та збагачується вуглекислим газом. Виділення $\mathrm{CO}_{2}$ в процесі дифузії залежить від продукування вуглекислого газу грунтом, фізичних та хімічних властивостей грунту, зміни гідротермальних умов. Вирішальну роль при цьому відіграють біологічні фактори, саме тому виділення $\mathrm{CO}_{2}$ може слугувати характеристикою інтенсивності біологічних процесів у грунті. Внаслідок цього інтенсивність дихання грунту $\epsilon$ одним із показників біологічної активності грунту.

Таблиця 1 - Вміст різних газів і летких органічних сполук в атмосферному і грунтовому повітрі [1]

\begin{tabular}{|c|c|c|}
\hline \multirow{2}{*}{$\begin{array}{c}\text { Гази і леткі } \\
\text { органічні } \\
\text { сполуки }\end{array}$} & \multicolumn{2}{|c|}{ Вміст, \% } \\
\cline { 2 - 3 } & в атмосфері & в грунті \\
\hline $\mathrm{N}_{2}$ & 79,1 & $68 \div 73$ \\
\hline $\mathrm{O}_{2}$ & 21,9 & $5 \div 21$ \\
\hline $\mathrm{CO}_{2}$ & 0,03 & $0,1 \div 20$ \\
\hline $\mathrm{H}_{2}$ & $5 \cdot 10^{-5}$ & $1 \div 8 \cdot 10^{-6}$ \\
\hline $\mathrm{CO}$ & $1 \cdot 10^{-5}$ & $1 \div 8 \cdot 10^{-6}$ \\
\hline $\mathrm{NO}$ & $1 \cdot 10^{-5}$ & $1 \div 10 \cdot 10^{-4}$ \\
\hline $\mathrm{N}_{2} \mathrm{O}$ & $5 \cdot 10^{-6}$ & $4 \div 40 \cdot 10^{-5}$ \\
\hline $\mathrm{CH}_{4}$ & $3 \cdot 10^{5}$ & $1 \div 8 \cdot 10^{-7}$ \\
\hline
\end{tabular}

Вивчення газового режиму грунту має надзвичайно важливе значення для агрохімічних та мікробіологічних досліджень Газовий режим грунту являє собою сукупність усіх взаємопов'язаних явищ: надходження газів у грунт та їх пересування по профілю грунту; зміна вмісту та складу газів у грунтовому повітрі в результаті поглинення чи виділення окремих газів при біологічних та біохімічих процесах, обміну між грунтом та атмосферою, твердою та рідкою фазами.

Загалом вивчення газової фази грунтів в екології та грунтознавстві має на меті два основні напрями [1]: 
1) оцінка родючості грунтів як середовища існування живих організмів та рослинних культур;

2) дослідження екологічної газової функції грунту як джерела газоподібних речовин відносно атмосфери.

Мета. Метою дослідження є обгрунтування можливості використання сенсорного методу для визначення складу грунтового повітря та синтез чутливого матеріалу на основі наноструктур стануму (IV) оксиду для детектування $\mathrm{CO}_{2}$.

Методика дослідження. Методи визначення дихання трунтів. Всі методи визначення дихання грунтів можна розділити на: методи збагачення $\mathrm{CO}_{2}$ в ізолюючому пристрої; методи провітрювання; методи адсорбції. В першому методі визначають початкову та кінцеву концентрації вуглекислого газу в повітрі ізолятора, встановленого на поверхні грунту. Визначення дихання грунту другим типом методів проводять шляхом протягування повітря через ізолятор, встановлений на поверхні грунту. Методи адсорбції реалізуються за допомогою розміщення над поверхнею грунту ємності з лугом, який безперервно поглинає $\mathrm{CO}_{2}$ [3].

При вивченні дихання грунту потрібно мати на увазі, що виділення $\mathrm{CO}_{2} 3$ грунту змінюється протягом року та протягом доби, тому визначати дихання грунту потрібно періодично протягом усього вегетаційного періоду в різний час доби. При порівнянні декількох дослідних ділянок вимірювання потрібно проводити одночасно на всіх ділянках у години максимального виділення $\mathrm{CO}_{2}$ (3 9 до 13 години дня). Для отримання достовірних результатів необхідно проводити декілька повторних вимірювань. Для оцінювання сезонної мінливості треба проводити масштабний моніторинг. Важливим є також визначення точки відбору проб повітря [4].

Перспективним методом визначення складу грунтового повітря може бути сенсорний «е-nose», що базується на використанні масиву датчиків - мультисенсорної системи. Ця система не вимагатиме використання реактивів і дасть змогу проводити визначення вмісту компонентів грунтового повітря, зокрема вмісту $\mathrm{CO}_{2}, \mathrm{O}_{2}, \mathrm{NO}_{x}$, в онлайн режимі.

Комериійні сенсори для визначення вмісту компонентів грунтового повітря

Сенсори $\mathrm{CO}_{2}$. Карбон (IV) оксид - у нормальних умовах газ без кольору та запа- ху, але має злегка кислуватий смак. Він $є$ продуктом життедіяльності усіх живих організмів на землі. Для контролю його концентрації використовуються блоки датчиків і сенсори (первинні перетворювачі) карбону (IV) оксиду, електрохімічні, оптичні та напівпровідникові сенсори.

Електрохімічні датчики карбону (IV) оксиду набули найбільшої популярності завдяки найкращому поєднанню ціни i достовірності показань. Сенсори карбону (IV) оксиду від швейцарської компанії Membrapor займають лідируючі позиції на ринку завдяки непоганій якості та великій кількості варіантів датчиків $\mathrm{CO}_{2}$ у номенклатурі виробника. Не поступаються за якістю і популярністю сенсори карбону (IV) оксиду від японської компанії Nemoto. Оптичні датчики $\mathrm{CO}_{2}$ мають найкращі характеристики за параметрами довговічності, надійності, селективності, але не завоювали широку популярність на ринку за рахунок високої вартості. Напівпровідникові датчики карбону (IV) оксиду мають найменшу вартість. До мінусів датчиків $\mathrm{CO}_{2}$ цього типу можна віднести нестабільність показань і перехресну чутливість до інших газів [5].

Сенсори $\mathrm{O}_{2}$. Кисень $\left(\mathrm{O}_{2}\right)$ не є токсичною речовиною, не має смаку, кольору і запаху. Його можна виявити за допомогою газоаналітичного обладнання, такого як блоки датчиків (вимірювальні перетворювачі) і сенсори (датчики) кисню. Найбільш популярними для визначення кисню $є$ електрохімічні, оптичні та полімерні сенсори.

Електрохімічні сенсори кисню набули найбільшого поширення. Електрохімічні датчики кисню - це осередок 3 електролітом i електродами, закритий фільтром. Застосовуються ці датчики кисню в стаціонарних і переносних газоаналізаторах. Оптичні датчики кисню мають більшу надійність і строк служби. Оптичні сенсори кисню застосовують у випадках, коли необхідна тривала експлуатація приладу без обслуговування. Основний виробник цих датчиків - фірма SST, Великобританія. Полімерні датчики кисню є новинкою в газоаналітиці, але їх принцип будови схожий з електрохімічними датчиками. Порівняно 3 електрохімічними сенсорами кисню полімерні менші за розміром і можуть комплектуватися в невеликих корпусах [6].

Сенсори $N O_{x}$. Нітроген (IV) оксиду $\left(\mathrm{NO}_{2}\right)$ - червоно-бурий газ з характерним їдким запахом. В атмосфері нітроген (IV) оксид 
$\epsilon$ серйозною небезпекою, оскільки здатний викликати токсичні ураження організму та кислотні дощі. В основному поширені тільки електрохімічні датчики $\mathrm{NO}_{2}$, що пов'язано 3 особливостями цього газу.

Електрохімічні датчики $\mathrm{NO}_{2}$ відрізняються високими показниками селективності, невисокою вартістю і різними варіантами номенклатури. Найбільш популярними на ринку є датчики для виявлення нітроген (IV) оксиду від компанії Membrapor. Це пов'язано 3 великим вибором діапазонів вимірювання, технічних характеристик і розмірів датчика. Не поступаються за якістю датчики $\mathrm{NO}_{2}$ від компанії AlphaSense, які виявляють найкращу чутливість на різних діапазонах вимірювання. Якісні сенсори $\mathrm{NO}_{2}$ також випускають компанії Sixth Sense i Nemoto. Полімерні датчики для детектування нітроген (IV) оксиду є новинкою в газоаналізі і на даний момент їх відрізняє низька ціна і довгий термін служби.
Проте ці сенсори $\mathrm{NO}_{2}$ поки не змогли зарекомендувати себе як сенсори 3 відмінними технічними характеристиками [7].

Нітроген (II) оксид (NO) - безбарвний газ, шкідливий для організму людини. Для детектування NO на сьогоднішній день використовують тільки електрохімічні датчики [8].

Дистаниійний моніторинг трунтового повітря. Розробка електронного носа (e-nose) для моніторингу повітря вже давно цікавить науковців через все більший інтерес до екології. Цей факт сприяє розробці та вдосконаленню методів і способів реалізації екологічного моніторингу. Так званий $e$-nose імітує нюхову систему людини і складається 3 декількох ключових елементів: системи доставки зразка повітря; системи аналізу, що складається 3 масиву газових датчиків; системи обробки сигналів та спеціального програмного забезпечення [9]. На рисунку 1 зображено блоксхему системи $e$-nose.

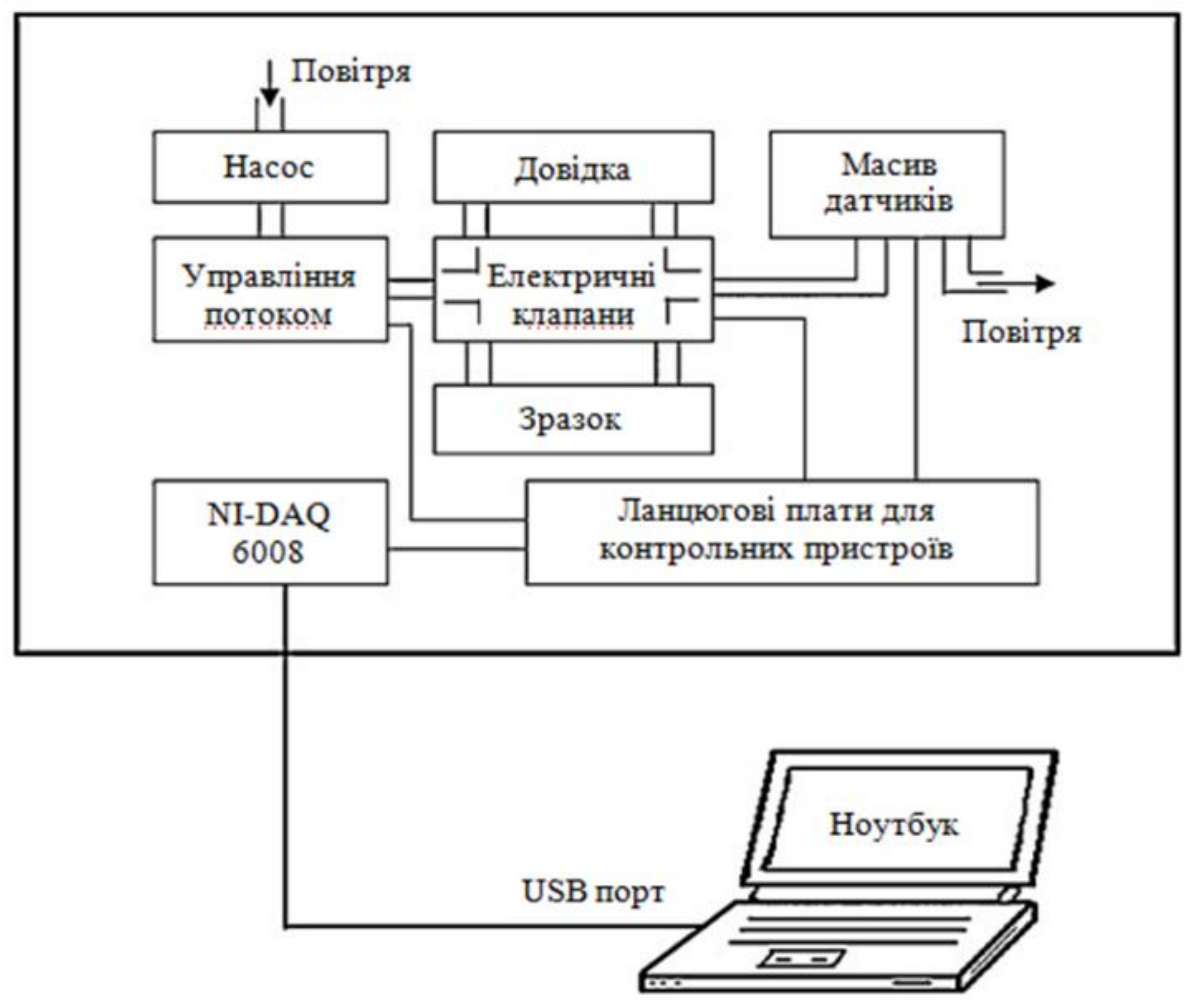

Рисунок 1 - Блок-схема системи e-nose [9]

Система доставки зразка повітря забезпечує відбір зразка до системи аналізу, що складається $з$ групи датчиків або сенсорного масиву, які реагують на компоненти газового середовища. Контакт групи датчиків або сенсорного масиву з газовим середовищем різного складу викликає зміни в електричних характеристиках цих датчиків. Таким чином, взаємодія змінює електричний сигнал, який перетворюється у цифрове значення [10].

На сьогодні розробка системи e-nose для моніторингу навколишнього середовища, 
в тому числі для моніторингу такого нового об'єкта, як грунтове повітря, становить великий інтерес через здатність цього приладу розпізнавати та розрізняти різні гази, використовуючи лише невелику кількість датчиків. При контролі якості повітря електронні носи можуть використовуватися як альтернатива газової хроматографії для оцінювання якості повітря [11-13]. Зрештою, електронні носи також можуть бути використані як інструменти керування процесом у режимі реального часу, тобто дадуть змогу проводити дистанційний моніторинг упродовж тривалого часу. Однак нині головним обмеженням поширення e-nose як засобів моніторингу навколишнього середовища $\epsilon$ їх складність та відсутність специфічного регулювання їх стандартизації, оскільки їх використання зумовлює необхідність великої кількості додаткових знань, наприклад щодо обробки даних. Також застосування $e$-nose є обмеженим через нестабільні та змінні умови. Незважаючи на це, системи $e$ nose вже використовуються для оцінювання забруднення повітря різних джерел, таких як сміттєзвалища, установки зі спалювання, компресорні установки та тваринницькі ферми [14].

Нині для розробки e-nose найперспективнішими $є$ такі мініатюрні газові сенсори: металоксидні (напівпровідникові), електрохімічні та оптичні [15]. Хоча напівпровідникові датчики споживають більше енергії, вони найбільш широко досліджуються для створення $e$-nose через низьку вартість і різноманітний вибір, як, наприклад, Серія TGS виробництва Figaro.

Системи $e$-nose інтенсивно створюються і розвиваються, але в таких галузях, як харчова індустрія, медицина, моніторинг повітря у приміщеннях. Нами не знайдено жодного дослідження, що присвячено створенню системи e-nose для моніторингу грунтового повітря. Отже, цей науковий напрям є актуальним i в умовах нашої країни, що $є$ аграрною державою, видається практично значущим та перспективним.

Результати дослідження. Сенсорні властивості синтезованих наноструктур $\mathrm{SnO}_{2}$. Наноструктури $\mathrm{SnO}_{2}$ різної морфології були отримані методом паро-газового транспорту зі стануму (IV) оксалату [16]. В процесі синтезу досліджували вплив параметрів про- цесу на характеристики та морфологію одержуваних порошків, зокрема вплив прекурсорів, температури, складу газового середовища та швидкості нагрівання. Було встановлено, що ріст одновимірних наноструктур відбувається при використанні стануму (II) оксалату, синтезованого $з$ оксалату амонію [17]. Подальші дослідження привели до висновку, що швидкість нагрівання має значний вплив на морфологію структур $\mathrm{SnO}_{2}$. Утворення округлих частинок нульвимірного стануму (IV) оксиду $\left(0 \mathrm{DSnO}_{2}\right)$ відбувалося за швидкості нагрівання 80 град/хв. Зниження швидкості нагрівання до 20 град/хв призводило до росту одновимірних витягнутих структур $\mathrm{SnO}_{2}$ $\left(1 \mathrm{DSnO}_{2}\right)$ [18].

Одновимірні наноструктури стануму (IV) оксиду були модифіковані ітрієм методом просочування. В результаті отримали зразок $1 \mathrm{DSnO}_{2}+\mathrm{Y} 3$ масовим вмістом ітрію $1 \%$.

Вимірювання чутливості синтезованих наноструктур $\mathrm{SnO}_{2}$ проводили шляхом зняття вольт-амперних характеристик на повітрі та в атмосфері цільового газу в діапазоні значень

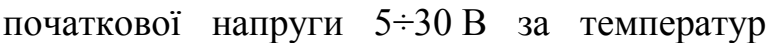
296 К та 323 К. Для проведення вимірювань в атмосфері цільового газу випробувальні структури поміщали в спеціальну трубку, через яку безперервно пропускали вуглекислий газ 3 концентрацією 1,2\%.

Вольт-амперні характеристики чистого та модифікованого ітрієм ниткоподібного $\mathrm{SnO}_{2}$, записані в повітряному середовищі в діапазоні значень початкової напруги $1 \div 9$ В

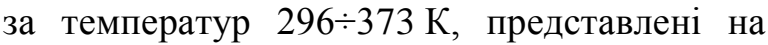
рисунку 2.

Як видно 3 представлених залежностей за температур, вищих 323 К, чисті та модифіковані ітрієм одновимірні наноструктури стануму (IV) оксиду характеризуються аналогічними, наближеними до омічних, вольтамперними кривими. Значною лінійністю відрізняються вольт-амперні характеристики немодифікованого $1 \mathrm{DSnO}_{2}$, зняті за кімнатної температури 296 K.

На рисунку 3 представлено температурні залежності опору синтезованих зразків стануму (IV) оксиду, одержані $з$ даними вольтамперних вимірювань. Для обох зразків $\mathrm{SnO}_{2}$ спостерігається наявність екстремуму за температури $323 \mathrm{~K}$. 

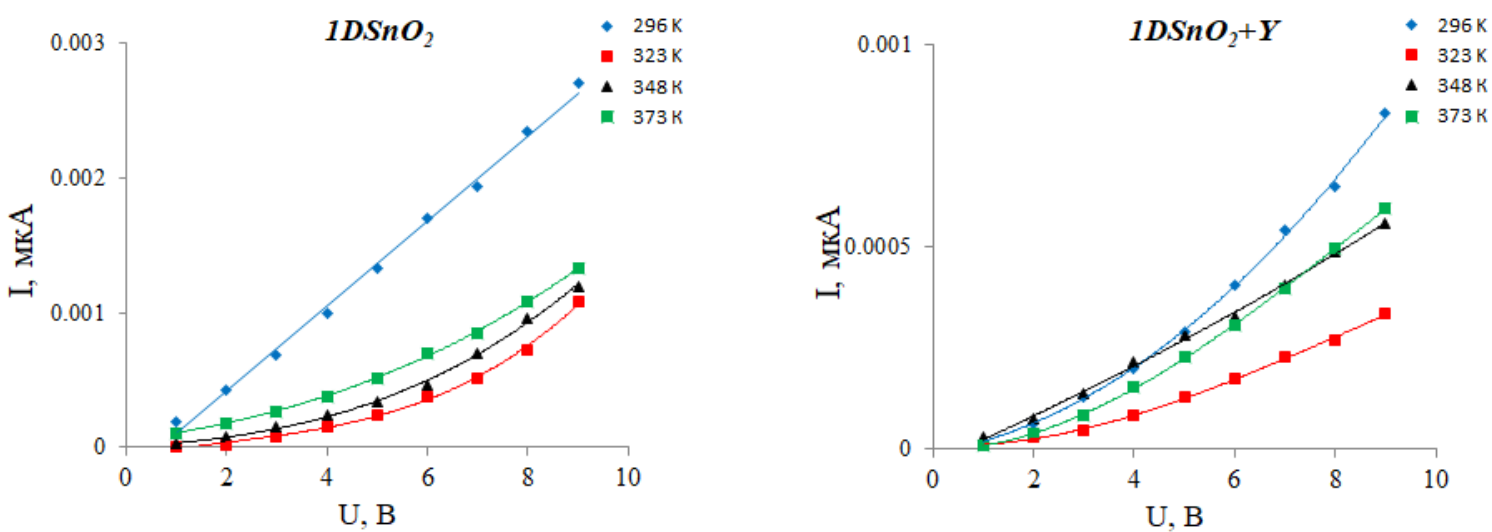

Рисунок 2 - ВАХ чистого та модифікованого зразків одновимірного стануму (IV) оксиду

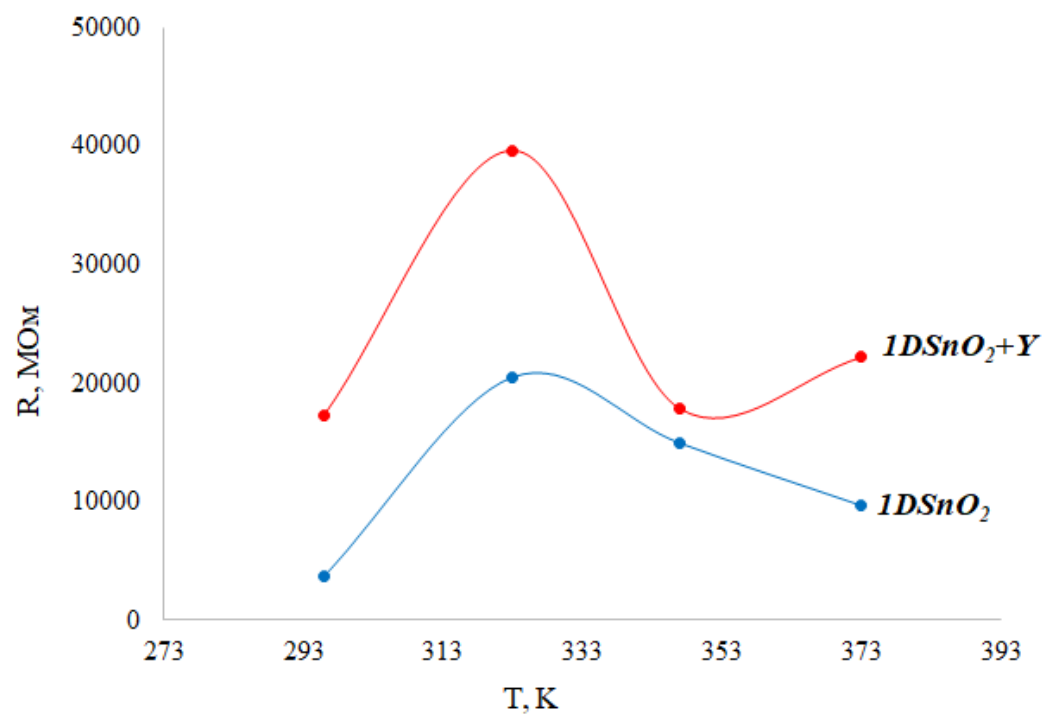

Рисунок 3 - Залежність електричного опору від температури чистого та модифікованого зразків одновимірного стануму (IV) оксиду за напруги 5 В

Чутливість визначали 3 урахуванням опорів чутливого шару в повітрі та в атмосфері цільового газу [19]:

$$
\mathrm{S}=\left(\mathrm{R}_{\Pi}-\mathrm{R}_{\Gamma}\right) / \mathrm{R}_{\Gamma} \times 100,
$$

де $\quad \mathrm{R}_{\text {п }}-$ опір чутливої плівки на повітрі; $\mathrm{R}_{\text {г }}$ - опір чутливої плівки в атмосфері вуглекислого газу.

Таблиця 2 - Значення чутливості наноструктур $\mathrm{SnO}_{2}$ до вуглекислого газу за температури $296 \mathbf{K}$

\begin{tabular}{|c|c|c|c|c|c|c|c|c|c|}
\hline \multirow{2}{*}{ Зразок } & \multicolumn{10}{|c|}{ Прикладена напруга, В } \\
\cline { 2 - 11 } & $1 \mathrm{~B}$ & $2 \mathrm{~B}$ & $3 \mathrm{~B}$ & $4 \mathrm{~B}$ & $5 \mathrm{~B}$ & $6 \mathrm{~B}$ & $7 \mathrm{~B}$ & $8 \mathrm{~B}$ & $9 \mathrm{~B}$ \\
\hline $1 \mathrm{DSnO}_{2}$ & 74,7 & 55,4 & 51,4 & 50,9 & 52,8 & 54,1 & 52,6 & 53,5 & 54,1 \\
\hline $1 \mathrm{DSnO}_{2}+\mathrm{Y}$ & 95,0 & 85,7 & 85,7 & 90,9 & 89,1 & 88,9 & 89,2 & 87,5 & 88,1 \\
\hline
\end{tabular}


Таблиця 3 - Значення чутливості наноструктур $\mathrm{SnO}_{2}$ до вуглекислого газу за температури $323 \mathrm{~K}$

\begin{tabular}{|c|c|c|c|c|c|c|c|c|c|}
\hline \multirow{2}{*}{ Зразок } & \multicolumn{10}{|c|}{ Прикладена напруга, В } \\
\cline { 2 - 12 } & $1 \mathrm{~B}$ & $2 \mathrm{~B}$ & $3 \mathrm{~B}$ & $4 \mathrm{~B}$ & $5 \mathrm{~B}$ & $6 \mathrm{~B}$ & $7 \mathrm{~B}$ & $8 \mathrm{~B}$ & $9 \mathrm{~B}$ \\
\hline $1 \mathrm{DSnO}_{2}$ & 85,1 & 51,4 & 48,1 & 59,2 & 56,6 & 58,8 & 53,7 & 62,6 & 50,1 \\
\hline $1 \mathrm{DSnO}_{2}+\mathrm{Y}$ & 99,0 & 96,7 & 80,0 & 77,8 & 78,6 & 78,9 & 76,0 & 75,0 & 64,9 \\
\hline
\end{tabular}

Як видно з одержаних даних, модифікований ітрієм зразок стануму (IV) оксиду характеризується вищими значеннями сенсорного відгуку порівняно з чистим $1 \mathrm{DSnO}_{2}$. При цьому підвищення робочої температури зі $296 \mathrm{~K}$ до 323 К незначно впливає на значення чутливості тестової сенсорної структури.

Висновки. В роботі проведено огляд щодо складу грунтового повітря, зокрема вмісту найбільш динамічних компонентів газової фази грунту $\mathrm{O}_{2}$ та $\mathrm{CO}_{2}$. Розглянуто існуючі методи визначення дихання грунтів та показано перспективність використання сенсорного методу, який дасть змогу проводити онлайн моніторинг складу грунтового повітря без використання реагентів та громіздкого обладнання. Для створення тестових структур напівпровідникових газових сенсорів методом паро-газового транспорту було синтезовано наноструктури стануму (IV) оксиду одновимірної морфології, проведено їх модифікацію ітрієм та дослідження електричних і сенсорних властивостей відносно $\mathrm{CO}_{2}$. Показано, що модифіковані ітрієм одновимірні наноструктури $\mathrm{SnO}_{2}$ мають вищий сенсорний відгук до вуглекислого газу порівняно з немодифікованим зразком, тобто $\epsilon$ значно перспективнішими для використання в сенсорних системах дослідження складу грунтового повітря.

\section{Список використаних джерел}

[1] А. В. Смагин, Газовая фаза почв. Москва: Изд-во МГУ, 2005.

[2] А. В. Наумов, Дыхание почвы: составляюшие, экологические функиии, географические закономерности. Новосибирск: Изд-во СО РАН, 2009.

[3] Определение интенсивности выделения $\mathrm{CO}_{2}$ из почвы (дыхание почвы). [Электронный ресурс]. Режим доступа: http://agrohimija24.ru/agrohimicheskiemetody/1860-opredelenie-intensivnosti- vydeleniya-so2-iz-pochvy-dyhaniepochvy.html.

[4] M. Mariusz, Z. Bożena, M. Guardia, and J. Namieśnik, "Current air quality analytics and monitoring: A review", Analytica chimica acta., 853, pp. 116-126, 2015.

[5] Газовые датчики и сенсоры. Углекислый газ $\mathrm{CO}_{2}$. [Электронный ресурс]. Режим доступа: http://www.gassensor.ru/ru/gas/ uglekislyi-gas-co2.

[6] Газовые датчики и сенсоры. Кислород $\mathrm{O}_{2}$. [Электронный ресурс]. Режим доступа: http://www.gassensor.ru/ru/gas/kislorod-o2.

[7] Газовые датчики и сенсоры. Диоксид азота $\mathrm{NO}_{2}$. [Электронный ресурс]. Режим доступа: http://www.gassensor.ru/ru/gas/ dioksid-azota-no2.

[8] Газовые датчики и сенсоры. Оксид азота NO. [Электронный ресурс]. Режим доступа: http://www.gassensor.ru/ru/gas/oksidazota-no.

[9] T. Agarwal, "How does an electronic nose work?", 2013. [Online]. Available: https://www.elprocus.com/electronic-nosework.

[10] P. Littarru， "Environmental odours assessment from waste treatment plants: Dynamic olfactometry in combination with sensorial analyzers "electronic noses", Waste Manag., 27, pp. 302-309, 2007.

[11] G. Korotcenkov, "Metal oxides for solidstate gas sensors: What determines our choice?", Mater. Sci. Eng. B., 139, pp. 1-23, 2007.

[12] C. L. Zhu, Y. J. Chen, R. X. Wang, L. J. Wang, M. S. Cao, and X. L. Shi, "Synthesis and enhanced ethanol sensing properties of $\alpha-\mathrm{Fe}_{2} \mathrm{O}_{3} / \mathrm{ZnO}$ heteronanostructures", Sensors and Actuators B, 140, pp. 185-189, 2009.

[13] D. Costello, R. J. Ewen, N. M. Ratcliffe, and P. S. Sivanand, "Thick film organic vapour sensors based on binary mixtures of metal 
oxides", Sensors and Actuators B, 92, pp. 159-166, 2003.

[14] L. Capelli, S. Sironi, and R. Del Rosso, "Electronic noses for environmental monitoring applications", Sensors (Basel), 14, pp. 19979-20007, 2014.

[15] J. He, L. Xu, P. Wang, and Q. Wang, "A high precise e-nose for daily indoor air quality monitoring in living environment", Integration, 58, pp. 286-294, 2017.

[16] S. V. Nagirnyak, V. A. Lutz, T. A. Dontsova, and I. M. Astrelin, "Synthesis and characterization of tin (IV) oxide obtained by chemical vapor deposition method", NanoScale Research Letters, 11:343, pp. 1-7, 2016.

[17] T. A. Dontsova, S. V. Nagirnyak, V. V. Zhorov, and Y. V. Yasiievych, " $\mathrm{SnO}_{2}$ nanostructures: effect of processing parameters on their structural and functional properties", NanoScale Research Letters, 12:332, pp. 17, 2017.

[18] S. V. Nahirniak, T. A. Dontsova, and Q. Chen, "Sensing properties of $\mathrm{SnO}_{2-}$ MWCNTs nanocomposites towards $\mathrm{H}_{2}{ }^{\prime \prime}$, Molecular Crystals and Liquid Crystals, 674 (1), pp. 48-58, 2018.

[19] S. Nahirniak, T. Dontsova, and I. Astrelin, "Directional synthesis of $\mathrm{SnO}_{2}$-based nanostructures for use in gas sensors", Nanochemistry, Boitechnology, Nanomaterials, and their Applications, 214, pp. 233-245, 2018.

\section{References}

[1] A. V. Smagin, The gas phase of soils. Moscow: Izd-vo MGU, 2005 [in Russian].

[2] A. V. Naumov, Soil respiration: components, ecological functions, geographical patterns. Novosibirsk: Izd-vo SO RAN, 2009 [in Russian].

[3] Determining the intensity of $\mathrm{CO}_{2}$ emission from the soil (soil respiration). [Online]. Available: http://agrohimija24.ru/agrohimicheskie-metody/1860-opredelenieintensivnosti-vydeleniya-so2-iz-pochvydyhanie-pochvy.html.

[4] M. Mariusz, Z. Bożena, M. Guardia, and J. Namieśnik, "Current air quality analytics and monitoring: A review", Analytica chimica acta., 853, pp. 116-126, 2015.

[5] Gas sensors and detectors. Carbon dioxide $\mathrm{CO}_{2}$. [Online]. Available: http://www.gassensor.ru/ru/gas/uglekislyigas-co2.

(C) А. А. Ромась, М. А. Гуцол, С. В. Нагірняк, Т. А. Донцова, 2020 DOI: $10.24025 / 2306-4412.2 .2020 .195836$
[6] Gas sensors and detectors. Oxygen $\mathrm{O}_{2}$. [Online]. Available: http://www.gassensor.ru/ru/gas/kislorod-o2.

[7] Gas sensors and detectors. Nitrogen dioxide $\mathrm{NO}_{2}$. [Online]. Available: http://www.gassensor.ru/ru/gas/dioksidazota-no2.

[8] Gas sensors and detectors.. Nitrogen oxide $\mathrm{NO}_{2}$. [Online]. Available: http://www.gassensor.ru/ru/gas/oksid-azotano.

[9] T. Agarwal, "How does an electronic nose work?", 2013. [Online]. Available: https://www.elprocus.com/electronic-nosework.

[10] P. Littarru, "Environmental odours assessment from waste treatment plants: Dynamic olfactometry in combination with sensorial analyzers "electronic noses", Waste Manag., 27, pp. 302-309, 2007.

[11] G. Korotcenkov, "Metal oxides for solidstate gas sensors: What determines our choice?", Mater. Sci. Eng. B., 139, pp. 1-23, 2007.

[12] C. L. Zhu, Y. J. Chen, R. X. Wang, L. J. Wang, M. S. Cao, and X. L. Shi, "Synthesis and enhanced ethanol sensing properties of $\alpha-\mathrm{Fe}_{2} \mathrm{O}_{3} / \mathrm{ZnO}$ heteronanostructures", Sensors and Actuators B, 140, pp. 185-189, 2009.

[13] D. Costello, R. J. Ewen, N. M. Ratcliffe, and P. S. Sivanand, "Thick film organic vapour sensors based on binary mixtures of metal oxides", Sensors and Actuators B, 92, pp. 159-166, 2003.

[14] L. Capelli, S. Sironi, and R. Del Rosso, "Electronic noses for environmental monitoring applications", Sensors (Basel), 14, pp. 19979-20007, 2014.

[15] J. He, L. Xu, P. Wang, and Q. Wang, "A high precise e-nose for daily indoor air quality monitoring in living environment", Integration, 58, pp. 286-294, 2017.

[16] S. V. Nagirnyak, V. A. Lutz, T. A. Dontsova, and I. M. Astrelin, "Synthesis and characterization of tin (IV) oxide obtained by chemical vapor deposition method", NanoScale Research Letters, 11:343, pp. 1-7, 2016.

[17] T. A. Dontsova, S. V. Nagirnyak, V. V. Zhorov, and Y. V. Yasiievych, " $\mathrm{SnO}_{2}$ nanostructures: effect of processing parameters on their structural and functional properties", NanoScale Research Letters, 12:332, pp. 17, 2017. 
[18] S. V. Nahirniak, T. A. Dontsova, and [19] S. Nahirniak, T. Dontsova, and I. Astrelin, Q. Chen, "Sensing properties of $\mathrm{SnO}_{2-}$ MWCNTs nanocomposites towards $\mathrm{H}_{2}$ ", Molecular Crystals and Liquid Crystals, 674 (1), pp. 48-58, 2018. "Directional synthesis of $\mathrm{SnO}_{2}$-based nanostructures for use in gas sensors", Nanochemistry, Boitechnology, Nanomaterials, and their Applications, 214, pp. 233-245, 2018.

\section{A. A. Romas, \\ M. A. Gutsol, \\ S. V. Nahirniak, $P h$. D., \\ T. A. Dontsova, Ph. D., associate professor \\ National Technical University of Ukraine \\ "Igor Sikorsky Kyiv Polytechnic Institute" \\ Peremogy ave., 37, Kyiv, 03056, Ukraine \\ PROSPECTS OF SENSOR METHOD USAGE FOR DETERMINATION OF SOIL QUALITY}

Investigation of soil air composition is an extremely important task because the content of soil gas phase components, in particular $\mathrm{CO}_{2}, \mathrm{O}_{2}$ and $\mathrm{NO}_{x}$, directly reflects soil fertility. The composition of soil air, the so-called "breath of the earth", plays an important role in the nutrition of plants and is an indicator of biochemical and biological processes that occur in the soil. The study of soil gas regime is extremely important for agrochemical and microbiological studies and is a set of all related phenomena: the flow of gases into the soil and their movement along the soil profile; changes in the content and composition of gases in the ground air as a result of the absorption or release of individual gases in biological and biochemical processes, the exchange between soil and atmosphere, solid and liquid phases. Carbon dioxide and oxygen are the most dynamic gases among all gases of ground air. The growth of plants depends on the concentration of $\mathrm{CO}_{2}$, and when it reaches its optimal concentration it is possible to accelerate the growth of the crop. Oxygen of ground air is essential for soil fertility and especially necessary for microbiological processes. It actively participates in chemical reactions of mineral and organic substances and is actively absorbed by the roots of plants and microbes in the process of their breathing. This paper reviews the composition of ground air, considers existing methods of soil breathing determination and shows the prospect of sensor method with online monitoring without reagents usage. In order to determine the sensitivity of synthesized samples towards $\mathrm{CO}_{2}$, one-dimensional nanostructures of the tin (IV) oxide have been synthesized by vapor transport method and their modification by yttrium for use in sensitive layers of gas sensor has been done. The current-voltage characteristics of pure and modified $\mathrm{SnO}_{2}$ nanostructures at ambient and in the atmosphere of carbon (IV) oxide have been investigated. It is shown that yttrium modified onedimensional $\mathrm{SnO}_{2}$ nanostructures have a higher sensory response to carbon dioxide in comparison with the pure tin (IV) oxide sample, that is, they are much more promising for use in sensing systems of soil air composition study.

Keywords: soil types, breath of the soil, tin (IV) oxide nanostructures, multisensory system, enose, closed soil system.

Стаття надійшла 14.01.2020

Прийнято 04.02.2020

(C) А. А. Ромась, М. А. Гуцол, С. В. Нагірняк, Т. А. Донцова, 2020

DOI: $10.24025 / 2306-4412.2 .2020 .195836$ 